\title{
Kajian Genius Loci Pada Kampoeng Heritage Kajoetangan Malang
}

\author{
Wiwik Dwi Susanti ${ }^{1 *}$, Dyan Agustin ${ }^{1}$, Fairuz Mutia ${ }^{1}$ \\ ${ }^{1}$ Lab Perancangan dan Kawasan Arsitektur, Progdi Arsitektur, Fakultas Arsitektur dan Desain, UPN “Veteran” Jawa Timur-1 \\ *Email: wiwikds.ar@upnjatim.ac.id; Telp.+62 852-228-677-289
}

\begin{abstract}
Abstrak:
Kampoeng heritage Kajoetangan merupakan salah satu kampoeng tematik di kota Malang. Kampoeng heritage Kajoetangan lebih ditonjolkan pada aspek kesejarahan, dimana kampoeng ini memiliki peranan penting dalam perkembangan Kota Malang pada masa kolonial Belanda. Sehingga pada saat ini masih banyak ditemukan rumahrumah yang memiliki langgam kolonial dan jengki. Pada tahun 2018 Pemkot Kota Malang mencanangkan kampoeng tersebut menjadi kampoeng wisata yang lebih menonjolkan karakter kesejarahannya. Dalam penelitiain ini berusaha untuk mengupas potensi genius loci yang tidak hanya pada aspek kesejarahan. Kesimpulan dari penelitian ditemukan bahwa genius loci di kampoeng Kajoetangan meliputi aspek tangible, intangible dan makna. Sehingga makna kampoeng Kajoetangan tidak hanya menonjol dari aspek kesejarahan tetapi karakter kampoeng kota juga menonjol aspek ekonomi, social dan budaya menjadi bagian yang menarik untuk dikembangkan juga. Penelitian ini menggunakan metode kualitatif dengan menggunakan pendekatan Genius Loci sebagai parameter dalam analisa data.
\end{abstract}

Kata Kunci: kampoeng Heritage Kajoetangan; Genius Loci; tangible; intangible; makna

\section{Latar Belakang}

Kampoeng Kajoetangan merupakan kampoeng tematik yang diresmikan pada April 2018 yang menonjolkan aspek kesejarahan (heritage). Apabila dikaitkan dengan sejarah Kota Malang maka kampoeng Kajoetangan berkaitan erat dengan perkembangan pusat kota terutama alun-alun kotak yang berada di pusat Kota Malang. Sedangkan Asal-usul nama Kajoetangan menurut kesaksian warga asli Malang yaitu Oei Hiem Hwie dan A. V. B. Irawan, bahwa di sepanjang koridor jalan Kajoetangan dulu setiap kanan-kiri ditanami pohon-pohon yang daunnya berbentuk telapak tangan yang mengembang. Pohon jenis ini juga ditanam di Taman Indrakila tapi kini sudah tidak ada lagi (Widodo dkk, 2006). Koridor Kajoetangan mulai menguat setelah dibangunnya Alun-Alun Kotak Malang sekitar 1822. Lokasi koridor ini memang sangat tepat untuk menuju ke arah alun-alun, sehingga koridor Kajoetangan menjadi sumbu utama dari arah Utara menuju pusat alun-alun Malang pada waktu itu. (Khakim, 2019) Tetapi seiring perkembangan waktu koridor Kajoetangan sudah mengalami banyak perubahan baik dari aspek fisik dan non fisik. Perubahan tersebut berdampak pada perkembangan kampoeng sebagai area penyangga koridor tersebut. Bangunan colonial yang menjadi wajah asli kampoeng Kajoetangan lambat laun sudah mengalami perubahan menjadi kampoeng kota. Kampoeng Kajoetangan yang identic dengan nilai kesejarahan sudah mulai hilang digantikan dengan bangunan baru, sehingga menghapus wajah asli kampoeng Kajoetangan. Identitas mulai pudar dan terlupakan.

Kampoeng heritage merupakan salah satu upaya Pemkot Kota Malang untuk menghidupkan kembali kawasan tersebut. Pada penelitian ini berusaha untuk mengkaji nilai-nilai genius loci dari kawasan tersebut, mengingat bahwa kawasan tersebut kaya akan nilai-nilai kesejarahan, religious, social dan budaya. Genius Loci "spirit of place" adalah proses keterkaitan manusia dengan lingkungannya, dimana bermukim atau menghuni adalah kegiatan berpijak dimana manusia dapat mengorientasikan dirinya sendirinya, dapat mengidentifikasikan dirinya dengan lingkungan, dimana tempat (locus) menjadi sesuatu yang lebih dari sekedar naungan (shelter) dan dimana hal ini dipadukan. Harapannya dengan mengetahui genius loci maka akan dapat mendukung Pemkot Malangg dalam mengembangkan kawasan tersebut sebagai salah satu upaya revitalisasi kawasan. Dengan memahami genius loci kawasan tersebut maka identitas kawasan maka akan terwujud.

\section{Metode}

Penelitian ini bertujuan untuk mengidentifikasi genius loci pada kampoeng heritage Kajoetangan, sehingga metode yang digunakan yaitu metode penelitian kualitatif. Metode penelitian kualitatif dengan cara dua tahap yaitu:

\subsection{Metode Pengumpulan Data}

Metode pengumpulan data primer dengan melakukan observasi langsung pada lokasi penelitian. Observasi ditekankan pada elemen-elemen genius loci yaiti aspek tangible dan intangible. Tahap observasi yaitu peneliti terjun 
langsung ke lokasi penelitian untuk mendapatkan data secara langsung dan menyeluruh untuk mengkaji lebih dalam tentang objek penelitian serta menggambarkan suasana dari lokasi penelitian, dan tahap terakhir Selain itu pengumpuan data sekunder dilakukan dengan jelajah pustaka yang berkaitan dengan teori-teori genius loci.

\subsection{Metode Analisis Data}

Analisa data dilakukan berdasarkan kerangka teori dari beberapa ahli untuk mendapatkan data fakta yang ada dilapangan. Analisis berupa elemen-elemen pembentuk Genius Loci "spirit of place" pada kawasan yaitu aspek intangible, tangible dan makna.

\section{Hasil dan Pembahasan}

\subsection{Genius loci}

Pemikiran Norberg-Schultz bertujuan untuk menelusuri kecerdasan lokal (Genius Loci) dari suatu tempat. Istilah "Genius Loci" berasal kepercayaan bangsa Romawi tentang adanya ruh yang menjaga suatu tempat (a guardian spirit). Ruh inilah yang memberikan hidup bagi masyarakat untuk hidup dan bermukim, mendampingi mereka dari mulai kelahiran hingga akhir hayat. Genius loci bersifat lokal, dan unik dari satu tempat ke tempat lain. Secara diagramatis, konsep untuk mengungkap genius loci suatu tempat tersaji dalam gambar 1 di bawah ini (Ekomadyo, 2018)

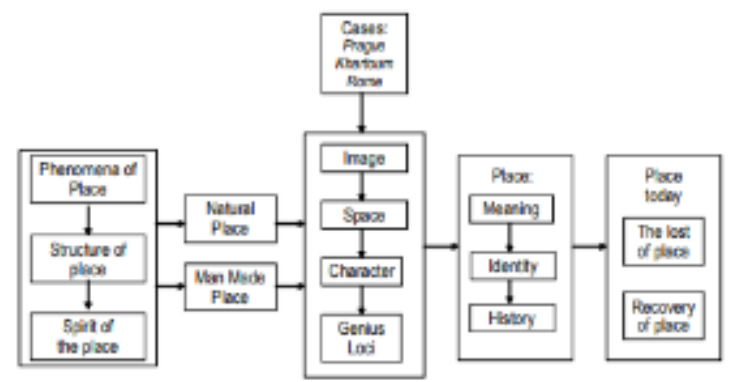

Gambar 1: Kerangka penelusuran genius loci

Sehingga dapat disimpullkan bahwa genius loci dapat ditelusuri dengan mengidentifikasi tiga elemannya yaitu: aspek tangible, intangible dan makna. Elemen pembentuk genius loci adalah hal-hal yang mendasari dari terjadinya pembentukan tempat itu sendiri yang menjadikan tempat tersebut berbeda dan memiliki ciri khas atau karakteristik yang berbeda dari tempat lain. (Gultom, 2018)

A. Aspek tangible yaitu:

Menurut Tibbalds 2001 mengatakan bahwa struktur ruang kota yang baik seharusnya memberi kemudahan bagi manusia, baik sebagai pejalan kaki, maupun pengemudi kendaraan, memberi petunjuk/ arah, dan elemen-elemen ruang ini, beserta landmark secara bersamaan membantu manusia dalam mengidentifikasi dan berorientasi dalam lingkungan nya.

Dengan demikian elemen Tangible (fisik) merupakan elemen yang dapat terlihat oleh mata dan perasaan seseorang ketika berada didalamnya yaitu sarana transportasi, pasar, pusat pemerintahan, ruang terbuka, pusat peribadatan, tempat permukiman, jalan, bangunan, area pejalan kaki, dan sebagainya

B. Aspek intangible yaitu:

Menurut Granham elemen Intangible (non fisik) adalah memori, narasi, dokumen tertulis, festival, acara peringatan, ritual, pengetahuan tradisional, makna, tekstur, warna, dan lain-lain. Dengan demikian yang dimaksud dari elemen Intangible (non fisik) adalah hal yang tidak dapat diraba melainkan bisa dilihat dari kegiatan maupun aktivitas yang dilakukan oleh manusia di lingkungannya tersebut yaitu: politik, sosial, aktivitas, budaya, urbanisasi, peningkatan kebutuhna ruang, peningkatan jumlah penduduk, dll. Elemen intangible (non fisik) ini berperan sebagai "spirit" terhadap tempat tersebut

C. Makna yaitu

Genius loci "spirit of place" menyangkut konsep makna (meaning). Menurut Schulz 1980 makna suatu objek terkandung di dalam hubungannya dengan objek lain, yaitu, apa yang telah dikumpulkan oleh objek tersebut, dengan demikian sebuah benda merupakan sebuah benda oleh nilai yang dikumpulkannya. Hal penting yang paling mendasar bagi manusia adalah membuat eksistensinya bermakna.

\subsection{Gambaran umum Kampoeng Kajoetangan}

A. Sejarah kampoeng Kajoetangan

Kampoeng Kajoetangan merupakan kawasan yang bersejarah karena pada era kolonial Belanda, kawasan ini menjadi jalan pusat yang menghubungkan arah Utara ke dalam pusat kota Malang yaitu alun-alun Malang sekitar 
1822. (Nasional Republika, 2019) Kajoetangan bukan hanya koridor utama tetapi lokasi bisnis. Hal ini terbukti dengan banyaknya kantor, pertokoan besar, dan restoran yang menyambung sepanjang Kajoetangan utara sampai selatan. Bahkan, koridor ini pernah dilintasi trem sehingga menjadi jalan utama. Kajoetangan pernah menjadi pusat perniagaan yang kelasnya bukan eceran. Bisa disimpulkan bahwa Kajoetangan sebagai tonggak perekonomian di Kota Malang. (Wulandari, 2012)

Hal ini dibuktikan dengan peninggalan yang dapat ditemui di kawasan ini yaitu bangunan-bangunan peninggalan Belanda masih dipertahankan bentuk aslinya terutama bentuk asli rumah dan pertokoan di perkampoengan Kajoetangan.
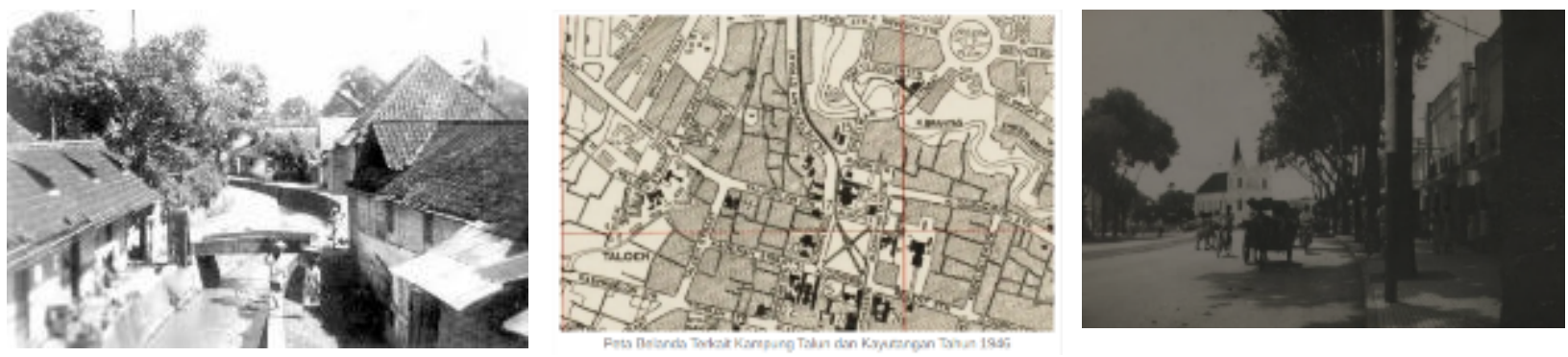

Gambar 2: Kampoeng Kayoetangan tempo dulu; Peta kampoeng Kayoetangan jaman kolonial; Koridor jalan Kayoetangan jaman kolonial

\section{B. Kampoeng Kajoetangan masa kini}

Kampoeng heritage Kajoetangan Malang terletak di sekitar pusat Kota Malang yaitu di Jalan Jend Basuki Rachmat Gg. VI, Kauman, Klojen. Sejak resmi dibuka pada 22 April 2018, Kampoeng Kajoetangan ini ditetapkan sebagai kawasan budaya (heritage) oleh pemerintah Kota Malang (Khakim, 2019).

Kampoeng Kajoetangan masa kini menjadi salah satu kampoeng tematik di Kota Malang karena potensi dan karakternya masih bisa ditelusuri sampai dengan saat ini. Beberapa bangunan bahkan masih bisa diidentifikasi secara jelas oleh pemiliknya yaitu terdapat Rumah Foto Galeri Antik, Rumah Jamu, Galeri Pak Eko Antik, Galeri Pak Udin, lalu ada Masjid Tua dan Rumah Punden. Di depan rumah Punden ada pertigaan kemudian belok kanan, di situ terdapat Gubug Ningrat, Rumah Jacoeb, Rumah Kaca Mata dan Galeri Abbas Akub. Ada banyak lagi fasilitas lainnya seperti Tangga 1000 Belanda, Pojok Dolanan, Kuburan Tanduk, Rumah Mbah Ndut, Makam Eyang Honggo Kusumo, Rumah Nyik Aisyah, Priambodo House of Kebaya, Rumah Tua, Rumah Pak Sakirman, Rumah Rindu, Pintu Jengki, Rumah Penghulu, Rumah Cerobong, Rumah Pak Hasan, Rumah Namsin, Pintu Rolak, Rumah Pijat dan Rumah Kartini. (Khakim, 2019)

Potensi tersebut menjadi daya tarik untuk dikembangkan dalam kampoeng tematik sehingga identitas dari kampoeng Kajoetangan tidak akan hilang.
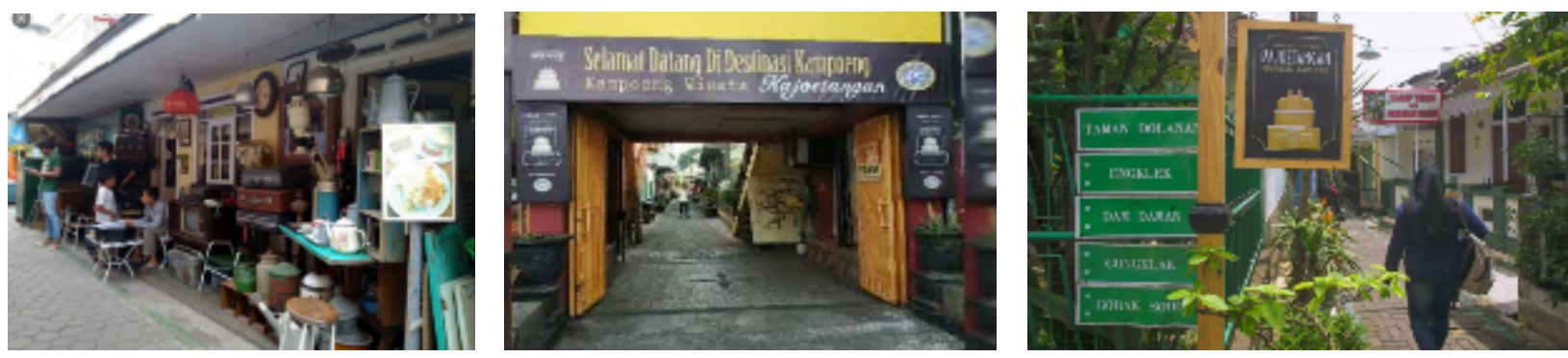

Gambar 3: Kampoeng Kajoetangan masa kini

\subsection{Analisa Genius Loci}

1. Elemen Tangile (Fisik)

Pada kampoeng Kajoetangan aspek tangible berhubungan dengan aspek kesejarahan dan sisa peradapan masa lalu berupa bangunan pertokoan, makam Eyang Honggo Kusumo, Pasar Krempyeng, saluran air, tangga seribu dan titik lainnya yang memiliki nilai sejarah yang tinggi di Kota Malang.

a. Langgam hunian

Pada saat ini di kampoeng Kampoeng Kajoetangan masih dapat dilihat peninggalan pada masa colonial dengan mengidentifikasi bentuk huniaannya yang masih memiliki style arsitektur jengki. Sehingga pada saat ini peninggalan tersebut sebagai bagian dari sejarah kota Malang yang masih terawat dengan baik. 

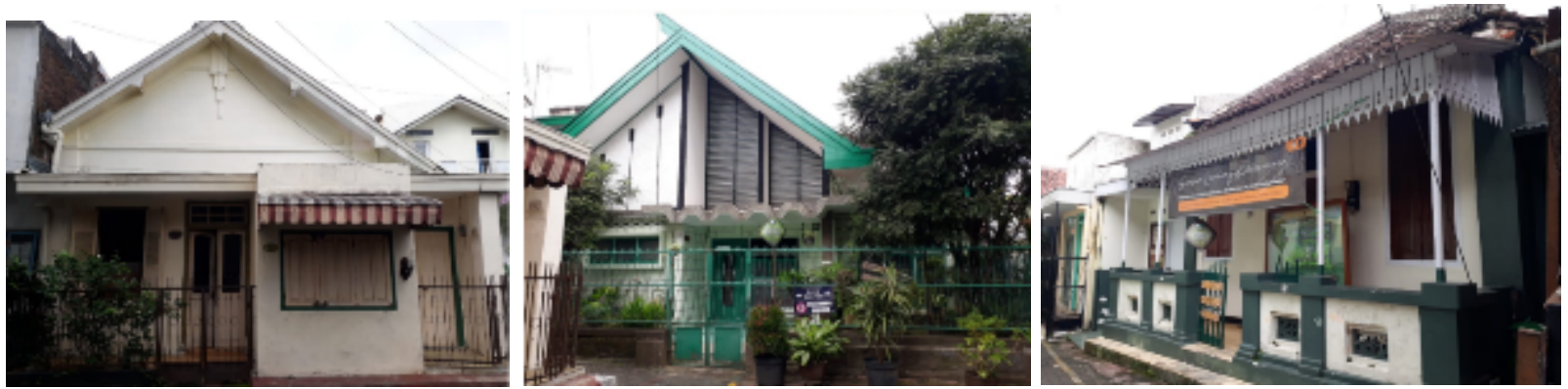

Gambar 4: Hunian di kampoeng Kajoetangan yang menggunakan style jengki

\section{b. Pasar Krempyeng}

Pasar krempyeng Kota Malang ternyata memiliki cerita menarik yang menjadi bagian sejarah perkembangan Kota Malang. Pasar Krempyeng atau Pasar Talun ini diperkirakan dibangun bersamaan dengan pembangunan beberapa pasar pembantu Kotapraja Malang yang dimulai tahun 1919, melingkupi pembangunan Pasar Bunulrejo, Pasar Klojen, Pasar Kebalen, Pasar Oro-Oro Dowo, Pasar Embong Brantas, dan Pasar Lowokwaru (Fathony, dkk. 2019). Namun, menurut versi lain keberadaan Pasar Krempyeng sudah ada sejak jaman Mbah Honggo. Pasar berada di tengah kepadatan penduduk Kajoetangan itu berlokasi di RW 01, kelurahan Kauman ini memiliki 3 los yang menempati area kurang lebih 50 x 30 meter persegi, terdiri dari 40 bedak.
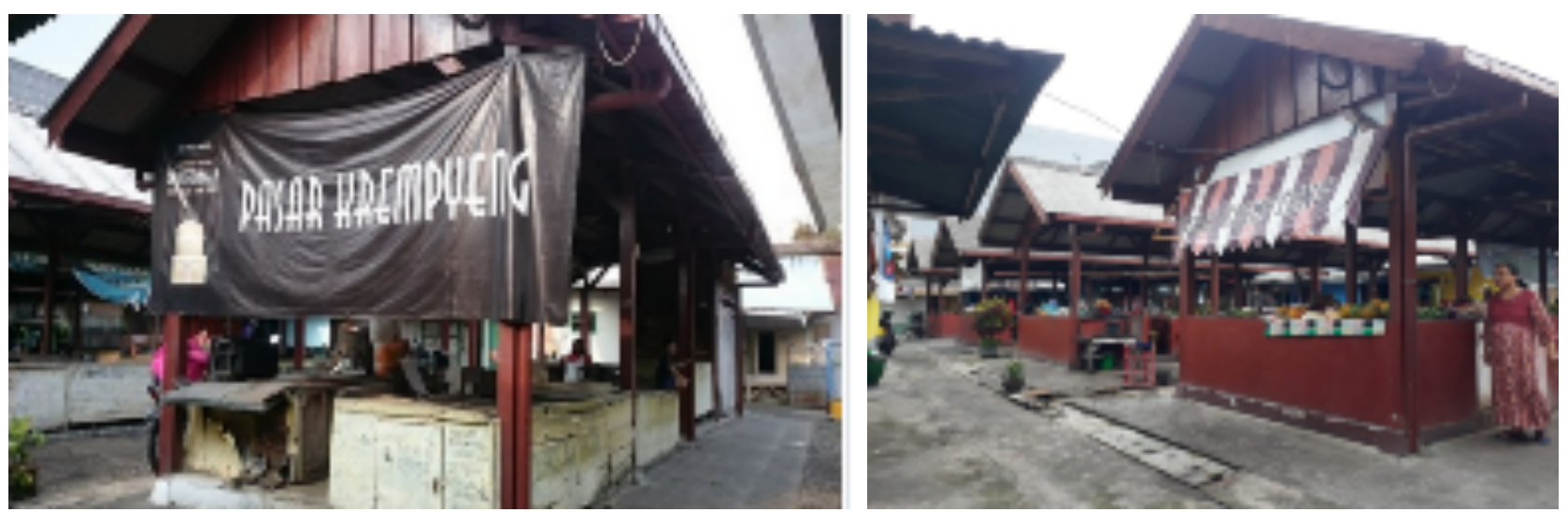

Gambar 5: Pasar Krempyeng

c. Makam Mbah Honggo Koesoemo

Sedangkan dari aspek budaya dan religi tidak lepas dari peran mbah Honggo atau Pangeran Honggo Koesoemo sebagai tokoh penyebar agama Islam di Talun. Mbah Honggo adalah guru rohani keluarga Bupati Malang yang pertama. Mbah Honggo dan makam disampingnya yaitu Pangeran Soero Adimerto atau Ki Ageng Peroet merupakah keturunan langsung dari Majapahit.

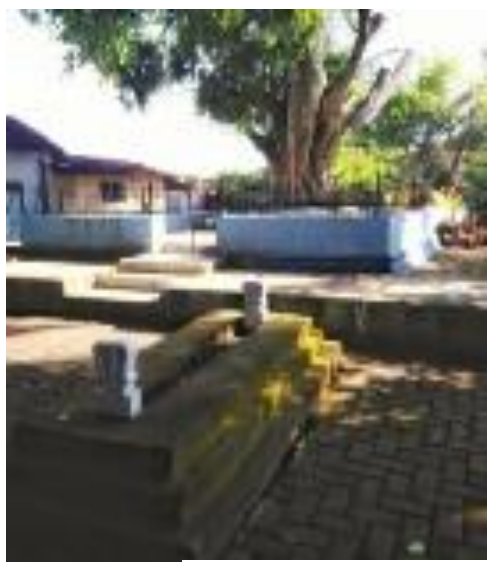

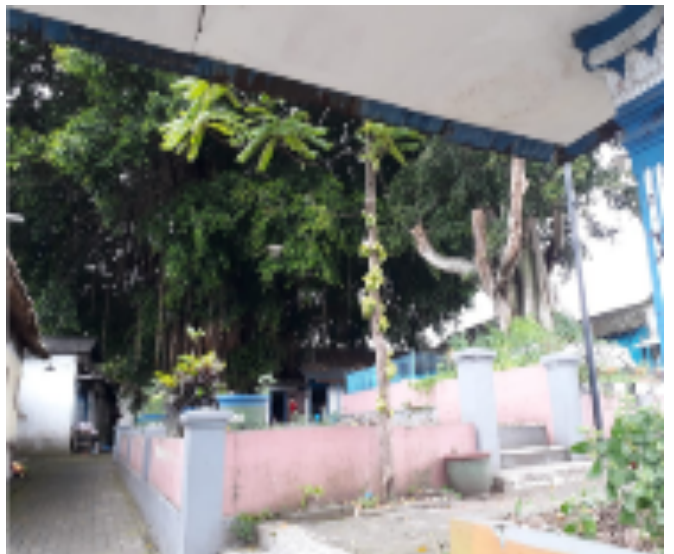

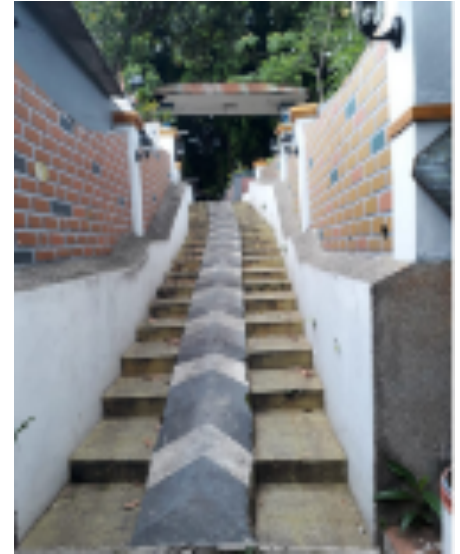

Gambar 6: Makam Mbah Honggo 


\section{d. Tangga Dorowati}

Tangga Dorowati merupakan salah satu daya tarik di kampoeng Heritage. Para wisatawan menyebutnya tangga 1000 karena jumlah anak tangga yang banyak dan curam. Tangga ini bisa diakses wisata dari arah Barat yaitu Jl Dorowati.

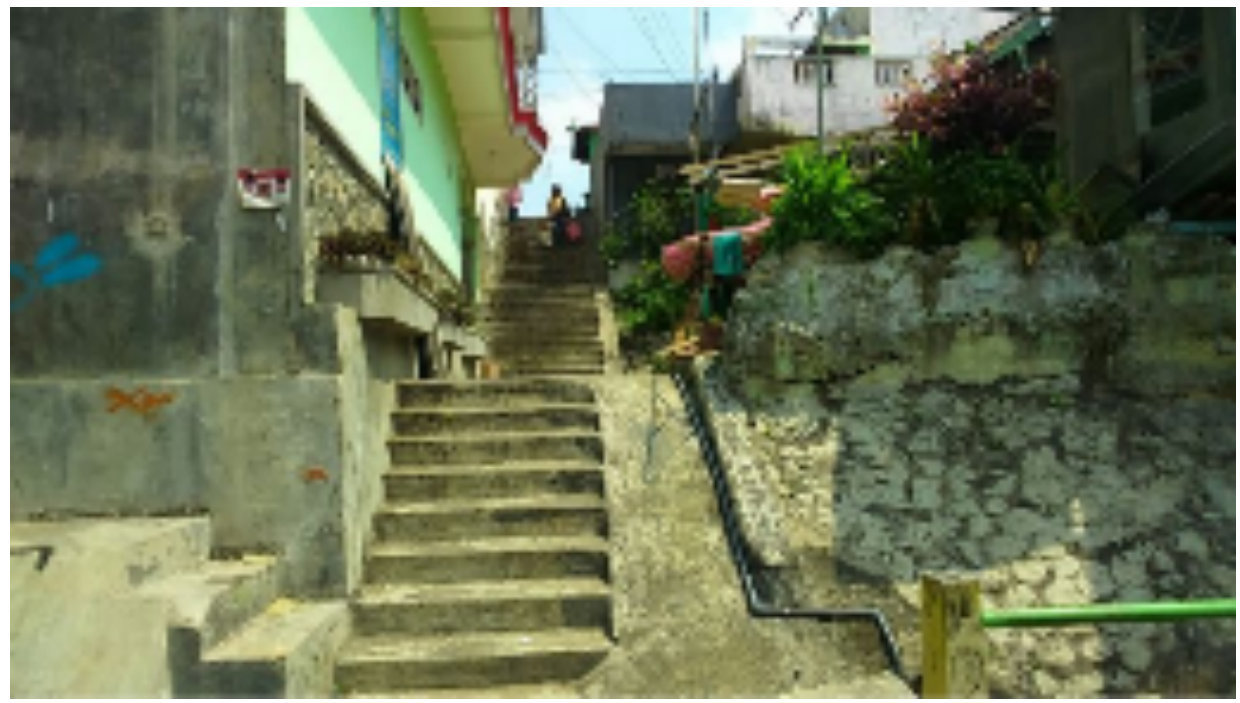

Gambar 7: Tangga Dorowati di Kampoeng Kajoetangan

e. Saluran drainase peninggalan Belanda

Wilayah Talun dibelah sungai kecil yang kemungkinan sungai ini merupakan saluran drainase primer, yang pernah direvitalisasi pada masa kolonial. Alirannya mulai dari ujung timur Oro-oro Dowo hingga bermuara di Kali Kasin. Saluran drainase ini memiliki aliran yang lurus dengan arah Utara-Selatan.

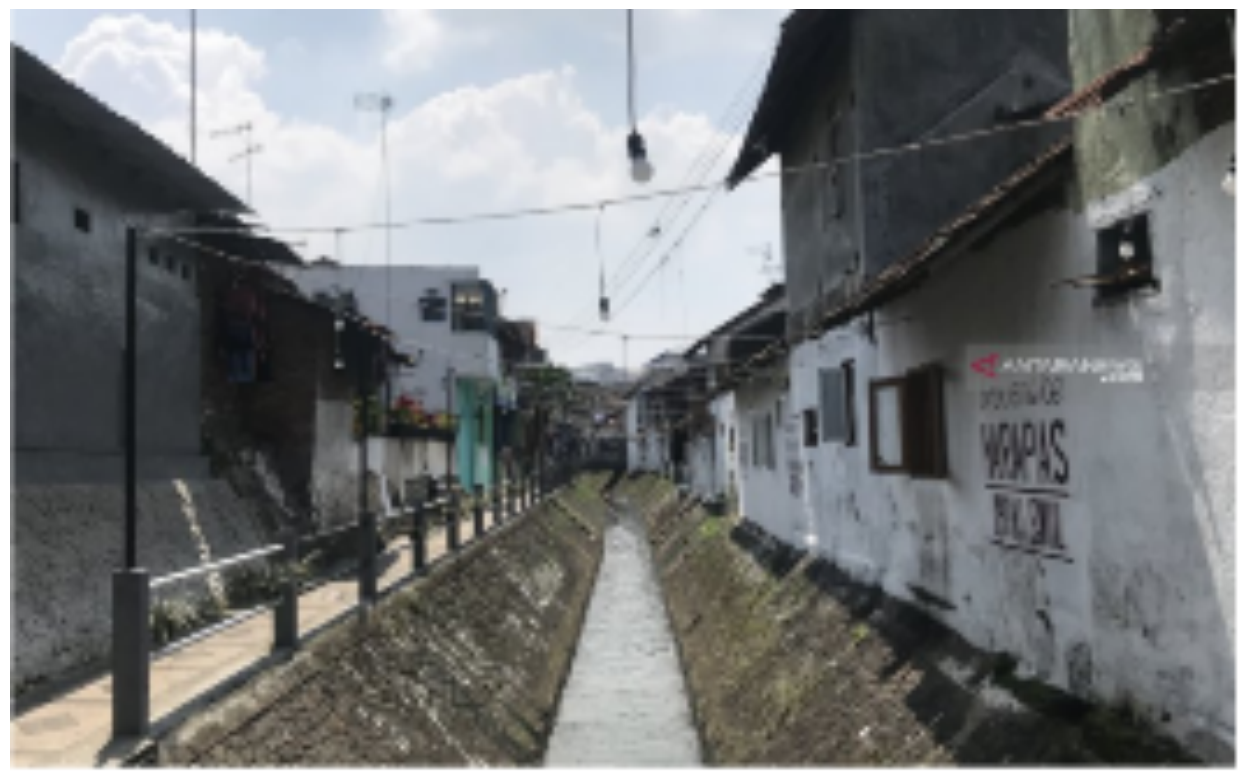

Gambar 8: Saluran drainase peninggalan Belanda

f. Café dan gallery tematik

Kegitan ekonomi warga juga didukung oleh warga dengan memanfaatkan rumah mereka yang memiliki tema arsitetur colonial. Ruamh trsebut disulap menjadi gallery yang menjual barang-barang antic sekaligus juga menyediaan café untuk pengunjung yang akan ngopi menikmati suasana kampoeng tematik. 

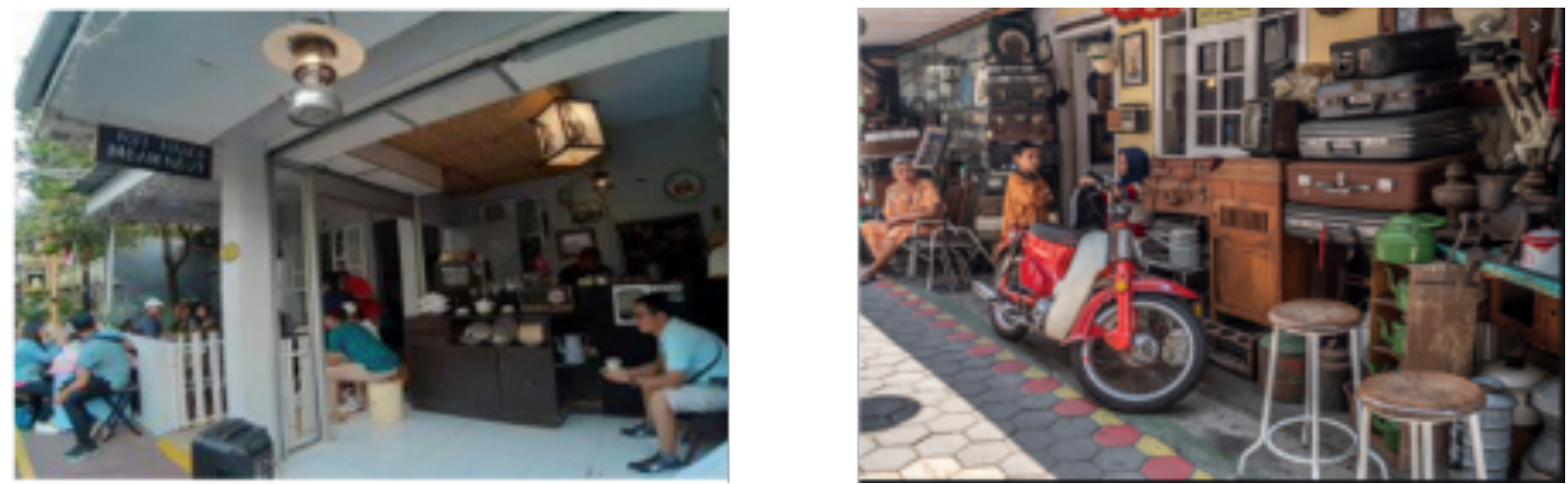

Gambar 9: Café dan gallery tematik

\section{g. Ruang social}

Ruang public menjadi bagian yang tidak terpisahkan pada kawasan kampoeng padat penduduk. Ruang public menjadi ruang social yang juga menjadi pusat kegiatan warga. Ruang public yang mendominasi pada kampoeng Kajoetangan berupa gang. Gang menjadi area sirkulasi sekaligus ruang social dan utilitas. Keterbatasan ruang terbuka di kampoeng padat penduduk menjadikan gang sebagai satu-satunya ruang public yang dapat mewadahi aktivitas social warga.
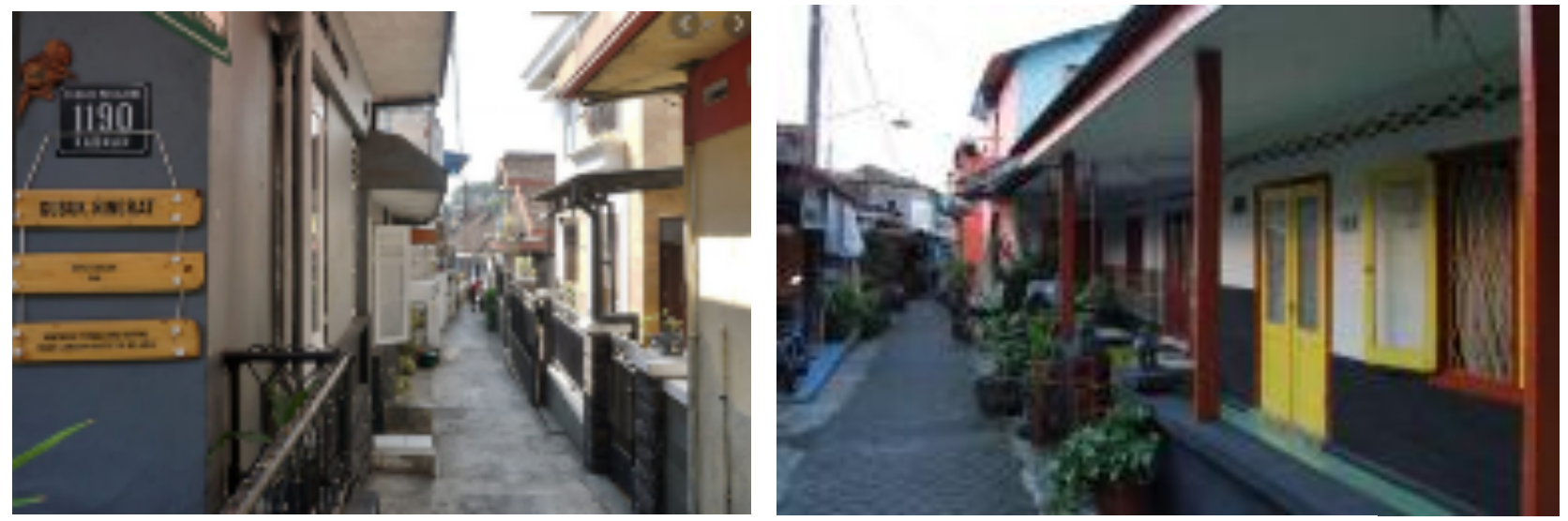

Gambar 10: Hunian di kampoeng Kajoetangan yang menggunakan style jengki

\section{h. Kampoeng padat penduduk}

Kampoeng Kajoetangan merupakan kampoeng padat penduduk yang lokasi tepat dijantung Kota Malang. Karakter kampoeng padat penduduk pada umumnya sama dengan karakter kampoeng Kajoetangan yaitu minimnya ketersediaan ruang public dan minimnya fasilitas umum. Akses masuk utama pada kampoeng Kajoetangan melalui gang-gang kecil yang hanya bisa diakses dengan sepeda motor dan pejalan kaki. Ruang public yang tersedia hanya berupa gang, sehingga gang digunakan sebagai jalur sirkulasi, social dan utilitas.
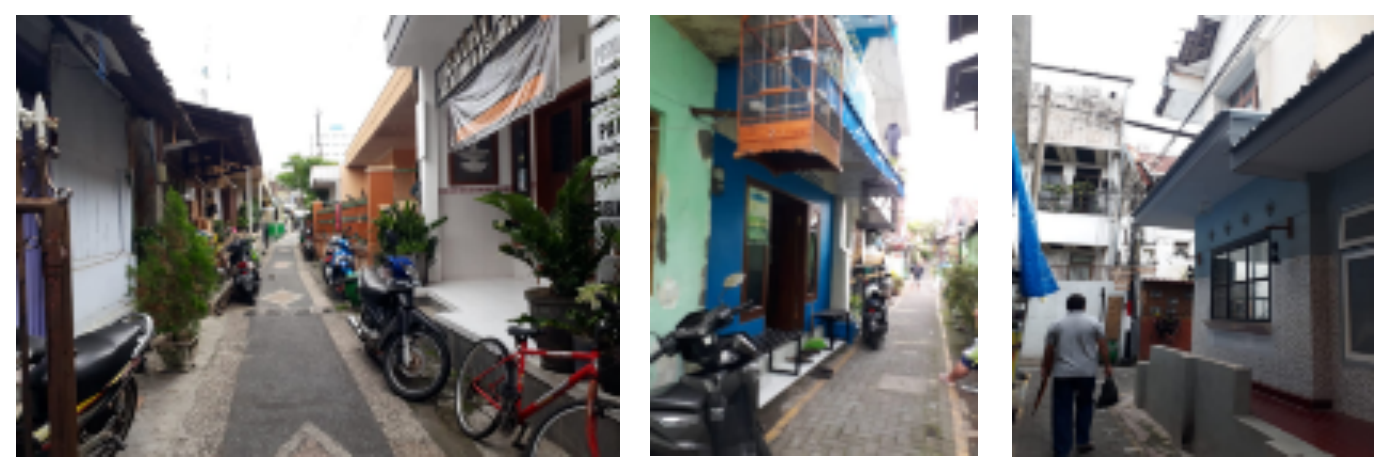

Gambar 11: Kampoeng Kayoetangan kampung padat penduduk 
i. Mural

Mural menjadi salah satu daya tarik dari kampoeng heritage Kajoetangan. Keberadaan mural menjadi obyek fotografi para pengumjung. Tema mural yang idpilihi disesuaikan dengan tema tempo doloe kota Malang.
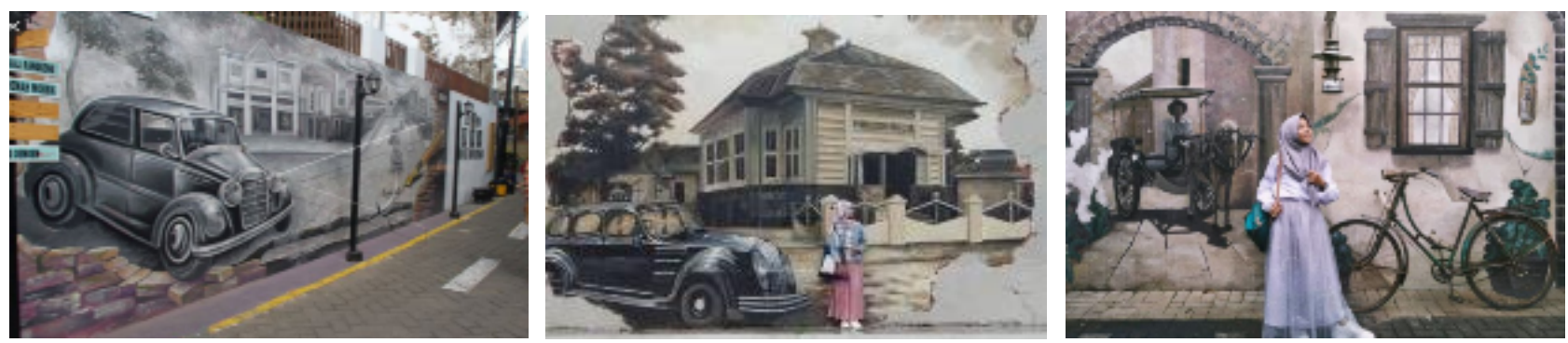

Gambar 12: Mural di Kampoeng Kayoetangan

\section{Elemen Intangible (Non Fisik)}

a. Aspek budaya dan religi

Sedangkan dari aspek budaya dan religi tidak lepas dari peran mbah Honggo atau Pangeran Honggo Koesoemo sebagai tokoh penyebar agama Islam di Talun. Mbah Honggo adalah guru rohani keluarga Bupati Malang yang pertama. Mbah Honggo dan makam disampingnya yaitu Pangeran Soero Adimerto atau Ki Ageng Peroet merupakah keturunan langsung dari Majapahit. Kegiatan nyekar merupakan kegiatan yang sering ditemui di makam Mbah honggo. Karena mbah Honggo merupakan sesepuh di daerah tersebut, sehingga peziarah tidak hanya berasal dari lokasi sekitar tetapi juga luar kampoeng heritage.

Selain kegiatan ziarah kegiatan bersih kampoeng juga biasanya dilaksanakan di makam Mbah Honggo Kusumo yang juga dihadiri oleh banyak orang. Kegiatan bersih kampoeng yaitu kegiatan tahunan yang memang bertujuan untuk memberi keselamatan semua warga kampoeng.
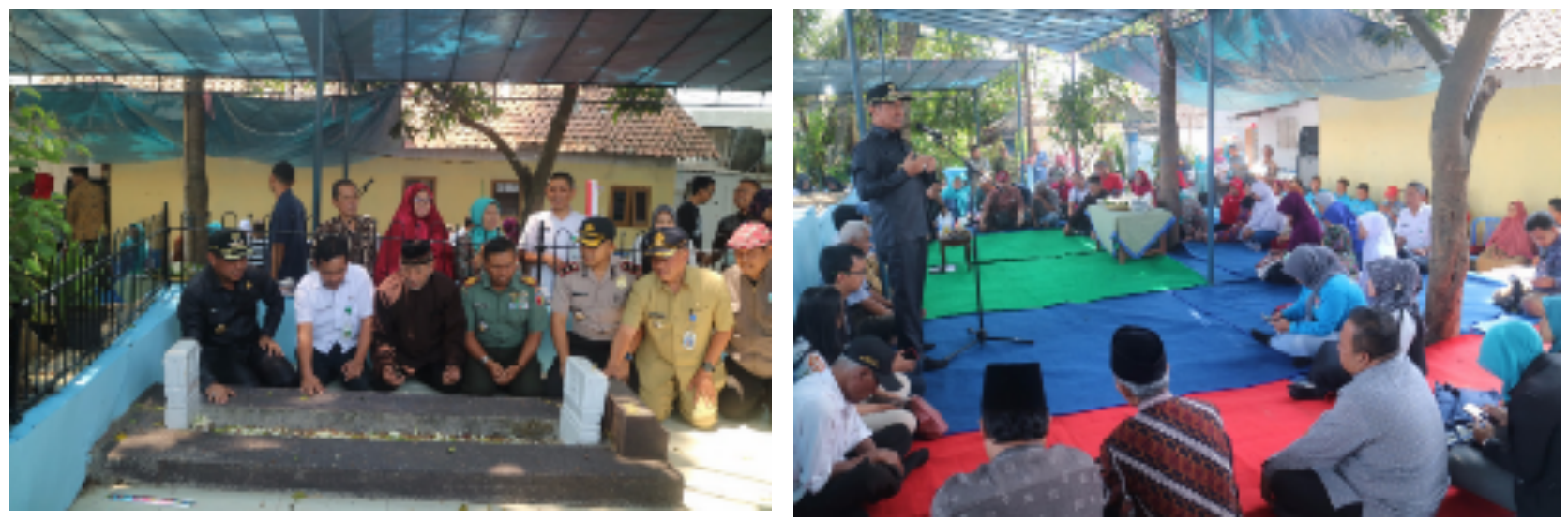

Gambar 13: Kegiatan ziarah di makam Mbah Honggo dan bersih kampoeng di

Kampoeng Kajoetangan

\section{b. Kegiatan social kampoeng kota}

Karakter kampoeng kota yang erat kaitnanya dengan kondisi social. Aspek social tersebut meliputi hubungan antar warga, dan kondisi ruang public yang mendukung kegiatan tersebut. Kampoeng Kajoetangan menrupakan kawasan padat penduduk di tengah kota, sehingga karakter masyarakatnya masih sangat menjunjung tinggi nilai kegotongroyongan. Ruang public banyak tersedia di kampoeng tersebut, gang menjadi ruang public multifungsi karena sebagian besar kegiatan warga dilakukan di ruang public. 

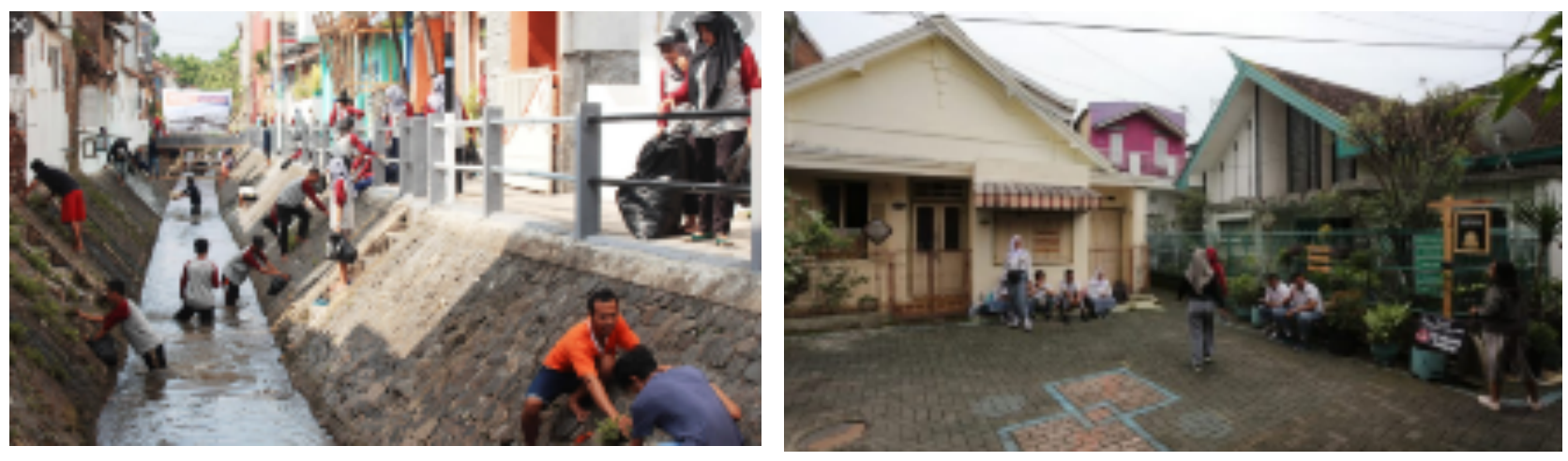

Gambar 14: Kegiatan warga dalam kegiatan sosial

Kampoeng Heritage Kajoetangan saat ini menjadi kampoeng tematik tidak lepas dari campur tangan warga setempat melalui Kelompok Sadar Wisata (POKDARWIS). Kelompok tersebut merupakan perwakilan warga yang menjadi jembatan dalam diskusi antara Pemkot Malang dengan warga. Sehingga warga ikut dilibatkan dalam melestarikan kawasan tersebut. Anggota Pokdarwis terdiri atas tiga rukun warga (RW), yaitu RW 1, RW 9, RW 10 dan baru bergabung RT 02. Pokdarwis Kajoetangan terus membenahi kampoeng sembari meningkatkan sumber daya manusianya.
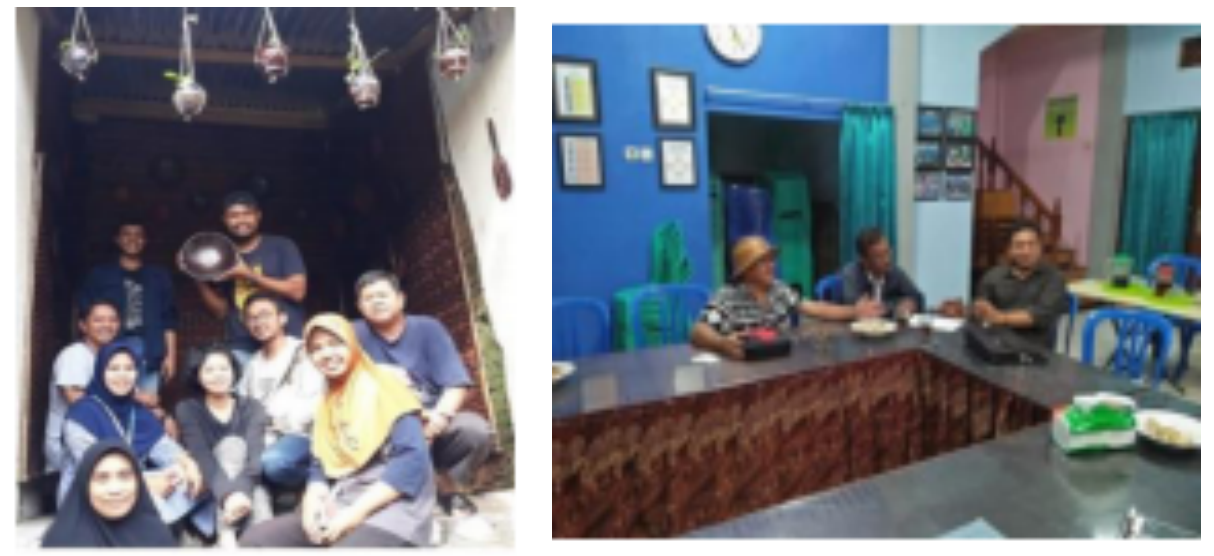

Gambar 15: Kegiatan POKDARWIS

c. Kegiatan wisata

Kampoeng Kajoetangan merupakan salah satu kampoeng tematik di Kota Malang, sehingga banyak wisatwan lokal dan asing yang berkunjung. Kegiatan yang sering dilakukan oleh wisatawan yaitu menelusuri sejarah kampoeng Kajoetangan dengan melihat sekaligu memotret rumah-rumah style jengki, wisatawan juga biasanya melakukan wisata belanja dengan membeli kerajinan khas kampoeng Kajoetangan, menikmati hidangan yang dijual warga setempat sekaligus berzirah pada makam mbah Honggo.
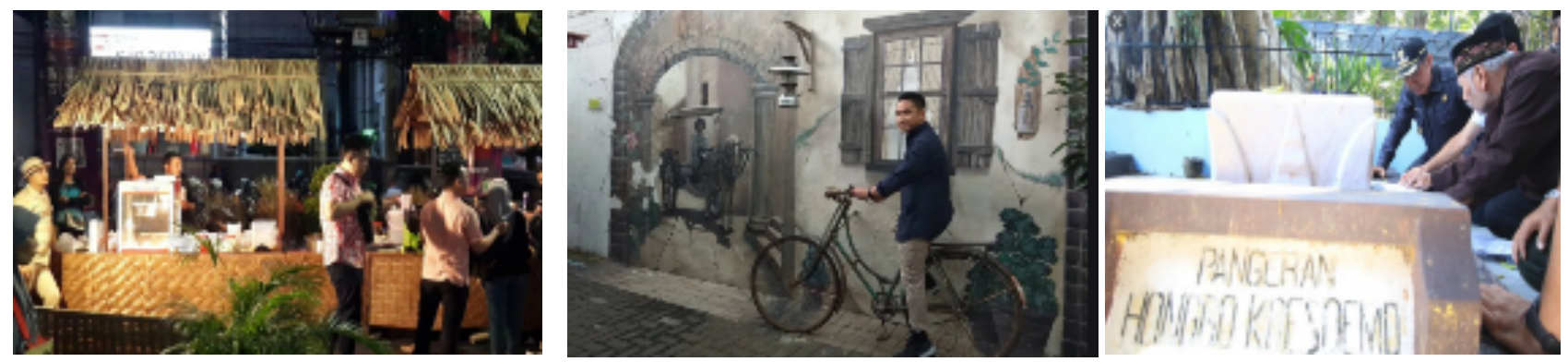

Gambar 16: Kegiatan Wisatawan 
d. Kegiatan budaya

Pada kampoeng Kajoetangan kegiatan yang berhubungan dengan kebudayaan masih sering ditemukan. Seni keroncong dan seni tari masih sering melakukan pertunjukan. Pertunjuan ini merupakan bagian dari agenda wisata kampoeng Kajoetangan. Kegiatan ini biasanya dilaksanakan di pasar krempyeng, wisatawan bisa berbelanja sekaligus menikmati pertnjukan tersebut.
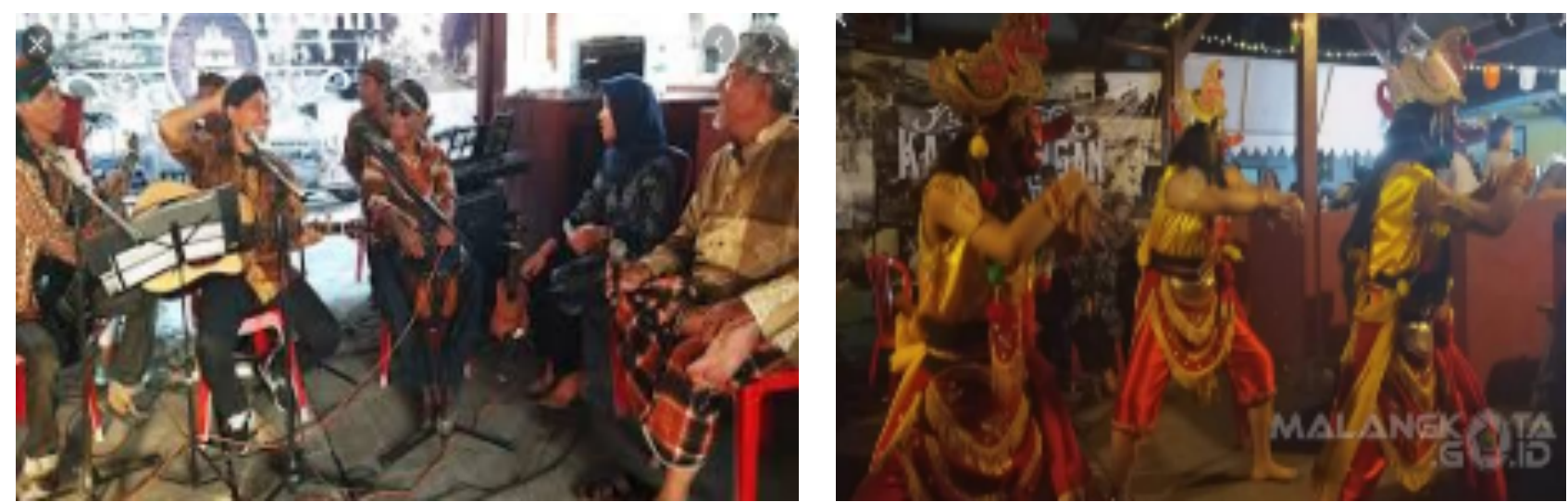

Gambar 17: Kegiatan Budaya

e. Kegiatan ekonomi

Karakter kampoeng kota yaitu banyak hadir kegiatan ekonomi yang dilakukan oleh warganya. Kegiatan ekonomi yaitu dengan memanfaatkan hunian sekaligus sebagai tempat untuk berjualan. Sehingga keberadaan toko ataupun tempat makan banyak ditemui di kampoeng tersebut.
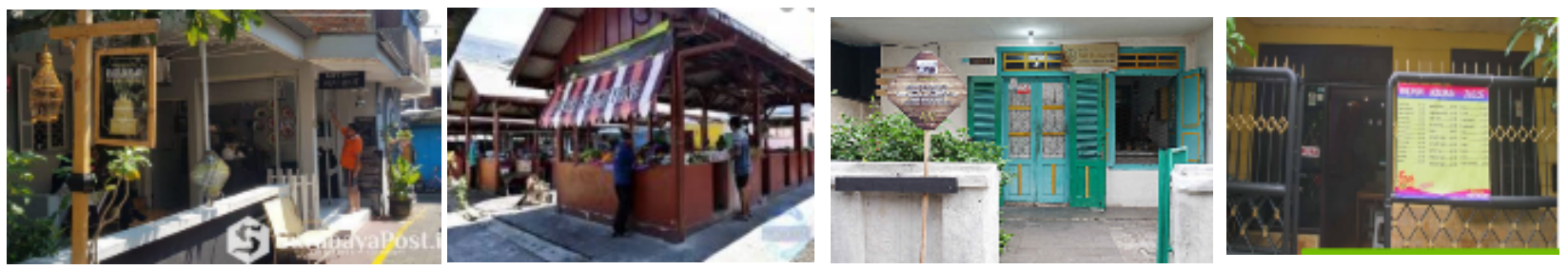

Gambar 18: Kegiatan ekonomi warga

\section{Elemen Meaning (Makna)}

Genius loci "spirit of place" menyangkut konsep makna (meaning). Menurut Schulz 1980 makna suatu objek terkandung di dalam hubungannya dengan objek lain, yaitu, apa yang telah dikumpulkan oleh objek tersebut, dengan demikian sebuah benda merupakan sebuah benda oleh nilai yang dikumpulkannya. Hal penting yang paling mendasar bagi manusia adalah membuat eksistensinya bermakna.

\begin{tabular}{llcl}
\hline No & \multicolumn{1}{c}{ Aspek tangible } & Aspek intangible & \multicolumn{1}{c}{ Meaning } \\
\hline $\mathbf{1}$ & $\begin{array}{l}\text { Rumah style colonial dan jengki, } \\
\text { toko, café, gallery, makam mbah } \\
\text { Honggo, pasar krempyeng, dan mural }\end{array}$ & Kegiatan Wisata & $\begin{array}{l}\text { Kampoeng wisata Kajoetangan } \\
\text { merupakan kampoeng tematik di } \\
\text { Kota Malang yang memiliki } \\
\text { nilai kesejarahan. Karakter } \\
\text { kampoeng kota juga terlihat dari } \\
\text { adanya kegiatan yang } \\
\text { berhubungan dengan kegiatan } \\
\text { social, ekonomi dan budaya. }\end{array}$ \\
\hline $\mathbf{2}$ & $\begin{array}{l}\text { Ruang public kampoeng } \\
\mathbf{3}\end{array}$ & $\begin{array}{l}\text { Mural, pasar krempyeng, makam } \\
\text { mbah honggo }\end{array}$ & Kegiatan Sosial \\
\hline $\mathbf{4}$ & $\begin{array}{l}\text { Kokgiatan budaya } \\
\text { Tokafé dan galery }\end{array}$ & Kegiatan ekonomi \\
\hline $\mathbf{5}$ & $\begin{array}{l}\text { Rumah-rumah style colonial dan } \\
\text { jengki }\end{array}$ & Aspek kesejarahan & \\
\hline
\end{tabular}

Berdasarkan hasil analisa maka meaning yang muncul di kampoeng heritage yaitu bahwa kampoeng heritage identic dengan kampoeng yang menonjolkan aspek kesejarahan tetapi disisi lain karakter kampoeng kota juga muncul. Sehingga kampoeng heritage Kajoetangan bisa dimaknai sebagai kampoeng yang menonjol dari aspek kesejarahan, social, budaya, religi dan ekonomi. 


\section{Kesimpulan}

Simpulan dari penelitian ditemukan bahwa genius loci di kampoeng Kajoetangan meliputi aspek tangible, intangible dan makna. Sehingga makna kampoeng Kajoetangan tidak hanya menonjol dari aspek kesejarahan tetapi karakter kampoeng kota juga menonjol yaitu aspek ekonomi, social dan budaya. Terdapat kolaborasi antara aspek kesejarahan didukung dengan potensi ekonomi, social dan budaya Sehingga perencanaan kampoeng tematik tidak hanya sekedar beautification melainkan menjadi jawaban dari permasalahan yang ada di kampoeng kota tersebut. Genius Loci merupakan salah satu cara untuk mengupas secara tuntas potensi yang dimiliki kampoeng kota tersebut.

\section{Daftar Pustaka}

Ekomadyo, Agus S. (2018). Menelusuri Genius Loci Pasar Tradisional sebagai Ruang Sosial Urban di Nusantara Proseding Seminar Penerapan Ilmu Pengetahuan Dan Teknologi 2018 E-ISBN 978-602-8355-70-4.

Fathony, Budi. dkk. (2019). Pelestarian Bangunan Cagar Budaya Di Kawasan Kajoetangan Kelurahan Kauman Kota Malang Studi Kasus Di Kampoeng Kajoetangan, Kota Malang. Proseding Seminar Nasional Infrastruktur Berkelanjutan 2019 Era Revolusi Industri 4.0 Teknik Sipil dan Perencanaan

Gultom, Bontor Jumaylinda Br, Saskia Oktrifani Sinaga. (2018). Identifikasi Genius Loci "Spirit of Place” Kawasan Jl. Sultan Muhammad, Pontianak. Seminar Nasional Penerapan Ilmu Pengetahuan Dan Teknologi

Khakim, Moch. Nurfahrul Lukmanul, dkk. (2019). Urgensi Pengelolaan Pariwisata Kampoeng Heritage Kajoetangan Malang, Jurnal Teori dan Praksis Pembelajaran IPS Volume 4, No.1, 2019, ISSN 2503-5307.

Khakim, Moch. Nurfahrul Lukmanul. (2019). Pengumpulan data lapangan di Kampoeng Heritage Kajoetangen.

MalangKota.go.id. (2019). Kampung Heritage KajoetanganKiniMiliki Pasar Krempyeng. Diakses pada 15 Juni 2020 dari https://malangkota.go.id/2019/10/27/kampung-heritage-kajoetangan-kini-miliki-pasar-krempyeng/

Norberg-Schulz, Christian. (1980). Genius Loci: Towards A Phenomenology of Architecture. New York: Rizzoli

Republika.co.id. (2019). Menyibak Sejarah Kampung Kajoetangan di Malang. Diakses pada 23 Juni 2020, dari https:/nasional.republika.co.id/berita/nasional/daerah/pq4b41328/gayahidup/travelling/19/04/15/ppz95q459menyibak-sejarah-kampoeng-kajoetangan-di-malang

SuryaMalang.com.Kayutangan, (2018) Kota Malang, wisatawanbisanikmatianekarumahlawas. Diakses pada 22 Juni 2020 dari https://suryamalang.tribunnews.com/2018/04/22/menyusuri-kampung-heritage-kayutangan-kota-malangwisatawan-bisa-nikmati-aneka-rumah-lawas

Tibbalds, Francis. (2001). Making People Friendly Towns: Improving the Publik Environment in Town and Cities, London, Spon Press.

Warungwisata.com. (2018). Kampung Kayutangan, Wisata Sejarah di Kota Malang. Diakses pada 1 Juni 2020 dari https://warungwisata.com/kampung-kayutangan-wisata-sejarah-di-kota-malang/

Widodo, Dukut Imam, dkk. (2006). Malang Tempo Doeloe Djilid Satoe. Malang: Bayoemedia

Wulandari, Lisa Dwi. (2012) Karakter Lokal Lansekap Perkotaan di Kota Malang Seminar Nasional SCAN\#3 